Annuaire du Collège de France 2017-2018

\title{
Religion, institutions et société de la Rome antique (2001-2016)
}

John Scheid

\section{OpenEdition}

1 Journals

Édition électronique

URL : https://journals.openedition.org/annuaire-cdf/16089

DOI : 10.4000/annuaire-cdf.16089

ISBN : 978-2-7226-0572-5

ISSN : 2109-9227

Éditeur

Collège de France

Édition imprimée

Date de publication : 30 décembre 2020

Pagination : 644-645

ISBN : 978-2-7226-0516-9

ISSN : 0069-5580

\section{Référence électronique}

John Scheid, «Religion, institutions et société de la Rome antique (2001-2016) », L'annuaire du Collège de France [En ligne], 118 | 2020, mis en ligne le 01 avril 2021, consulté le 22 août 2022. URL : http:// journals.openedition.org/annuaire-cdf/16089; DOI : https://doi.org/10.4000/annuaire-cdf.16089 


\section{RELIGION, INSTITUTIONS ET SOCIÉTÉ DE LA ROME ANTIQUE (2001-2016) \\ John SCHEID \\ Membre de l'Institut (Académie des inscriptions et belles-lettres), professeur émérite}

\section{RECHERCHE}

\section{Projet « Fana, Templa, Delubra » (FTD)}

Les travaux ont continué, d'une part aux fascicules : le $5^{\mathrm{e}}$ fascicule consacré à la Région X, Trieste, Emona, a été mis en ligne et imprimé ; de l'autre à la mise au point de l'interface de consultation de la base de données en ligne, qui sert d'index à l'ensemble de la collection. Le fascicule consacré à Ostie a été mis en ligne et imprimé et a été publié en automne $2019^{1}$.

\section{Publication de fouilles}

En collaboration avec H. Broise (architecte retraité de l'IRAA) et F. Bessière, J. Scheid a mené plus avant le travail aux manuscrits de la publication de ses fouilles à La Magliana (Rome), dont le manuscrit sera remis à l'imprimeur en été 2020, et à Djebel Oust (Tunisie) dont la préparation est en cours.

Le 28 juin 2018, J. Scheid a été nommé membre du conseil scientifique du Fonds national de la recherche dans le secteur public (Luxembourg).

\section{PuBLications}

\section{Ouvrage}

SCHEID J., La religion romaine en perspective, Paris, Collège de France, coll. «Leçons de clôture », 2018 ; en ligne : https://books.openedition.org/cdf/5365.

\section{Articles}

SCHEID J., « Rituelle Handlungen auf der Trajans- und der Marcussäule - Ein Vergleich », in F. MitTHOF et G. SCHÖRNER (éd.), Columna Traiani - Traianssäule. Siegesmonument und Kriegsbericht in Bildern, Beiträge der Tagung in Wien anlässlich des 1900. Jahrestages der Einweihung, 9-12 mai 2013, Tyche, Sonderband 9, 2017, p. 145-150.

SCHEID J., «Quelques données sur les rites de fondation des temples romains », in S. AGUSTABoUlarot, S. HUber et W. VAN ANDRINGA (dir.), Quand naissent les dieux. Fondation des

1. FTD 5 : https://books.openedition.org/cdf/5041; FTD 6 (Ostia) : https://books.openedition. $\mathrm{org} / \mathrm{cdf} / 6426$. 
sanctuaires antiques : motivations, agents, lieux, Rome/Athènes, École française de Rome/ École française d'Athènes, coll. de l'École française de Rome vol. 534, 2017, p. 239-245.

SCHEID J., « Réflexions sur la falsification et le faux dans la Rome antique », in H. GABER, N. GRIMAL et O. PERDU (dir.), Imitations, copies et faux dans les domaines pharaonique et de l'Orient ancien, Actes du colloque Collège de France-Académie des inscriptions et belleslettres, Paris, 14-15 janvier 2016, Paris, Aibl-Soleb, coll. «Études d'égyptologie », vol. 16, 2018, p. 304-319.

SCHEID J., «Mythe d'un toponyme », in A. Bouet et C. PETIT-Aupert, Bibere, ridere, gaudere, studere, hoc est vivere. Hommages à Francis Tassaux, Bordeaux, Ausonius, coll. « Mémoires », vol. 53, 2018, p. 187-189. 